\title{
SYLVIA TOWNSEND WARNER AND THE RHAPSODIC PASTORAL
}

\begin{abstract}
Jane Feaver
In a diary entry for April 11 1 , 1930 , Sylvia Townsend Warner describes a supper spent with the young literary critic, William Empson. She was thirty-six and the more established writer, with a couple of collections of verse and three successful novels under her belt. Empson was twenty-three. His first book-length study, Seven Types of Ambigutity, was due to be published by Warner's publisher, Chatto and Windus, later that year. Nevertheless, 'I had gone a little frightened,' Wamer says, 'fearing it might be a party of intellectual young things...' She caricatures herself as a 'timid grandmother', and goes on to commend Empson for the untidiness of his room, the ad-hoc domesticity of his cooking arrangements, as if he had contrived both in an effort to put her at her ease.
\end{abstract}


This supper turned out to be no more than a footnote in each of their respective lives. Yet for anyone interested in the pastoral, or, more specifically, where Sylvia Townsend Warner stood in relation to the pastoral, it tantalizes with a sense of missed opportunity. From the perspective history affords I would like to re-visit their meeting, and in so doing identify a particular version of pastoral which - while it would not have been possible without Empson's recovery and explication of the word was a version Warner, under his nose, would make her own.

In that same diary entry of 1930 , Warner, no longer feigning the "timid grandmother', goes on to describe the bones of her discussion with Empson:

We argued quite naturally about Eliot, and Windham Lewis [sic] and Richardson... The argument was that I complained W.L. had A Message. He was of the opinion that poets should have a message, should be in touch with real life. I didn't see then, but I do know [now] that they should be so much in touch etc. that they don't want to alter it. It is a drawing-room or study contact with real life which wants to move the groundsel off the landscape.

(Warner, 1994 p.57)

Though neither writer mentions it directly, notions of "pastoral' hover around their conversation. Empson appears to be arguing that having a 'message' is indicative of being 'in touch with real life'. It is an argument that would resurface in the essays published as Some Versions of Pastoral (1935), a collection that almost single-handedly restored 'pastoral' to respectable literary discourse. In the first essay, Emspon, drawing on an overtly political and contemporary version of pastoral, argues that the main purpose of the form is to put the 'complex into the simple' (1935b, p. 25); it seeks to include 'everything' in 'the humble thing, with mystical respect for poor men, fools, and children' (p. 24). Under 
these auspices 'proletarian writers' become pastoral ones. Women, on the other hand, who by virtue of their 'outsider' status might equally qualify, in Empson's own terms, as both subject and, more pertinently, as practitioners of pastoral, are notable by their absence.

By the early 1930s Sylvia Townsend Warner already had a body of work that would situate her naturally in the pastoral as opposed to the urban literary tradition. Yet she herself refrained from using the word to describe her writing. In the England of the 1930s and 40s 'pastoral' among the urbane literary intelligentsia had come to represent a hackneyed, outdated mode, ripe for satire. Cold Comfort Farm, for instance, was published in 1932; and Warner herself would make the distinction 'truthful pastoral', in connection with her long poem Opus 7 (1931), as if she were articulating an oxymoron (Warner 2007 , p.5). Yet instinctively, in recording her conversation with Empson, she reaches for a pastoral metaphor. She equates 'real life' to the native, untidy 'landscape'; the 'groundsel' she mentions is a common, creeping weed.

Warner's deployment of the image reveals in Empson an assumed hierarchy: the writer - distinctly male - is seen to pronounce from the 'drawing-room' or the 'study', marshalling the landscape in support of his 'message'. Her instinct, on the contrary, is to be non-prescriptive, located outside, on the ground; her duty, no more than to reflect what she sees about her.

In a lecture, 'Women As Writers', given to the Royal Society of Arts in 1959, Warner points out with mock sympathy that men are likely to be weighed down with 'heavier equipment of learning and self-consciousness'. Women, through their upbringing and circumstance, find it easier to 'dress down': they have a facility for 'workaday democracy, an case and appreciativeness in low company' that fits them for the peculiar perspective pastoral - in Empson's 'proletarian' guise - purports to represent. When a woman enters the 'palace' of literature, she does so, Warner maintains, "by the pantry window', 'breathless and unequipped' (1982a, p.271). 
Warner does not wholly begrudge the exclusion; she is fully aware of the advantages such a lowly, unconventional entry affords. In the Sylvia Townsend Warner archive there are several pages of a typescript relating to the manuscript of The Corner That Held them (1948), the novel she worked on throughout the distuptions of the Second World War. Among those pages Warner describes with admiration the particular quality of a nun:

A person who is almost a common person, who comes of a family which has risen in the world by unassisted merit, and whom God has hauled up a little further by the gift of a good cducation and polite circumstances, but who yet retains the blessedness of the poor in heart and does not put on airs, should be able to mix very comfortably in a party of pilgrims.

Warner is not disingenuous about her own background or education. But what she values is willingness to dress down and not up, an ability to 'mix very comfortably' (if not invisibly) among the motley crowd that might make up a 'party of pilgrims'.

Holidaying as a child in the Ettrick Valley, Warner had loved to watch the shepherds at work, commenting, "If when the war of 1914-1918 came there had been a demand for shepherdesses I think I would have volunteered for such work' $(2007$, p.3). Her literal leaning towards the pastoral is shared by the protagonist of her critically and commercially successful first novel, Lolly Willowes (1926). Lolly's progression towards fulfilment is rendered as a conversion to the pastoral life, one characterized by leaving the city and divesting herself of material things: 'It is best as one grows older to strip oneself of possessions, to shed oneself downward like a tree' (1978, p.106). In the hunt for a final resting-place Lolly looks for, "a suitable dry ditch ...she would penetrate into a wood and burrow herself a bed' (p.247). 
Waner had once horrified her nurse by wanting to take home the rubbish - 'broken boots, old billycans' - left behind by tramps in the ditches: 'my nurse would say to the other nurses that I was a child with low tastes'(2007, p.1). Although the nurse's use of 'low' is entirely derogatory, it is, by implication, exactly the level of observation and association Warner recommends. In an astute early review of the novel, L.P. Hartley draws attention to Warner's 'admirable low tone' comparing it favourably to that of Defoe, whose works in the 'common tongue', it turns out had been a great influence on her (Gamett, 1994, p. 66).

In the early 1930 s, Wamer left London to live in a small Dorset village, an eccentric though not unprecedented decision for a writer, and a move that politically signalled her commitment to the countryside. In 1935 like many liberal intellectuals she joined the Communist Party. Years later she explained: "I became a Communist simply because I was agin [sic] the Government'. Her true sympathies she said, were with the anarchists: 'You've always got something to be anarchic about - your life is one long excitement' (Schmidt, 2002 p. 46). When asked whether the relationship between political anarchism and the formal control evidenced in her writing was not incompatible, Warner retorted by paraphrasing Walt Whitman, "Am I inconsistent? Well, I am inconsistent. Within me I contain millions!' (p.50).

If Empson cxpounds a single thesis in Some Versions of Pastoral, it is that assertion of the process by which the pastoral manages to put the 'complex into the simple'. To explain what he means he comes up with the nonec-word pantification, offering the following definition: 'treating the symbol as everything that it symbolizes, which turns out to be everything'(1995b, p.25). There is an obvious congruity here between Warner's creative attitude of inclusion and Empson's definition of the process. It is a link made more tangible through the example of a poet cited by both writers: Andrew Marvell. And it is Marvell's particular facility for metaphor which becomes the defining feature of a rhapsodic version of pastoral that 
Empson by implication endorsed and in which Warner categorically excelled.

Alexaner Pope, in his Discourse on Pastoral Poetry (1717) requires that above all a pastoral should bc 'delightful'. He is highly prescriptive in terms of subject; yet in outlining a methodology, based on a requirement for 'variety', he offers a mode full of imaginative potential:

This variety is obtain'd in a great degrec by frequent comparisons, drawn from the most agreeable objects of the country; by interrogations to things inanimate; by beautiful digressions, but those short; and lastly by clegant turns on the words...

(p.299)

It is that requirement of pastoral to delight, predicated on a native ability to transform itself, that makes it the natural recourse of both the message-maker and the pleasure or comfort-secker. 'Country life,' as Raymond Williams tells us in his compendious study, The Cotmtry and the City (1973) is 'an innocent alternative to ambition, disturbance and war' (p. 36). For the propagandists of the $1930 \mathrm{~s}$ and $40 \mathrm{~s}$, the pastoral was a gift, used indiscriminately to fuel an alternative, patriotically revitalized image of England. What it offers is 'the metaphorical but also the actual retreat' (Williams, 1973 p.35). Metaphor presents both the vivifying conundrum and opcrating principal of pastoral: it looks like a real space and yet it is not real; it is not real and yet there is a reality or a truth in the fact that it does not pretend to be anything other than what it is, a reflection of what is real.

In a letter to her American publisher, Ben Huebsch, after bombing raids on London, Warner describes the city: 'St Clement Danes is a most romantic ruin, exactly like a Piranesi print. One expects to sce hooded shepherds from the Campagna sitting around it' (1982b, p.81). She makes a virtue of the perceived inadequacy of the 
classical pastoral image to reflect 'reality'. In drawing attention to the artificiality of the scenc - 'a Piranesi print': classical ruins rendered through an eighteenthcentury sensibility - she plays upon the trope as a distancing mechanism, using it to sublimate the turbulence of present war-time reality by appearing to privilege a purely visual aesthetic.

Though emotion is kept at bay, it is by no means absent. When Warner insists, 'exactly like', her tone is surely ironic. Such bright, over-insistence on the visual connection plays upon a wartime spirit of the "stiff upper lip'. The disjunction in terms of the present horrors of wartime blitz and its opposite in the untroubled extemporal pastoral scene requires a supreme feat of imagination. The sustained cffort cmbodied in the two super-imposed images is what adumbrates so subtly the depth of emotion at stake. Warner exploits the pastoral's innate ability to encompass both the temporary and the ex-temporary, or as Seamus Heaney puts it, 'the actual conditions of our daily lives' from the 'imaginative representation of those conditions in literature' (Heaney, 1995 p. xix).

It is a delicate balance. Empson warns of the pitfalls of a mode that lends itself to pitching 'style' against 'theme' - a 'clash' (1995b, p.17) that makes the pastoral so ripe for parody: the writing can too easily become 'funny', or descend to bathos. Warner flirts with that danger here, yet masterfully avoids it with the addition of that adjective 'hooded'. There is a sinister glimmer in those 'hooded shepherds' of another agriculturally inspired image: the grim reaper.

The subject of the novel she worked on throughout the War could not have been more far removed from it. In The Corner That Held Them Warner details over a period of thirty years the practicalities and vicissitudes of life in a fourteenth century convent. Gaston Bachelard has instructive things to say about corners and about delight: "I shall then show that a human being likes to "withdraw into his corner," and that it gives him physical pleasure to do so $(1969$, p.91). Warner claims to have chosen her 
corner because it offered her a 'sturdy tradition of the ordinary' (Warner 1948, p.91) and was 'the cpitome of humdrum' (Warner 1948, p.124); but it is clear from the momentum of its linguistically-based construction that what the novel truly hopes to derive from its comer is pleasure.

The Corner That Held Them was deliberately, provocatively, experimental. Warner describes it in a letter as having, 'no conversations, and no pictures, it has no plot, and the characters are innumerable and insignificant' (1982b, p.91). She makes it sound as near a recipe for disaster as she can make it, anarchic in its flagrant disregard for the realist conventions of the novel. Yet there is method in it, and perhaps no coincidence that if we look back to Pope's prescription for the pastoral, we might find in his recipe for rendering 'delightful' a perfect explication of Warner's chosen form.

In Seven Types of Ambiguity (1930), Empson quotes the critic Herbert Read (who, incidentally, considered himself an anarchist):

Metaphor is the synthesis of several limits of observation into one commanding image; it is the expression of a complex idea, not by analysis, nor by direct statement, but by a sudden perception of an objective relation.

(1995a, p.20)

Five years later Empson was to deploy that word 'complex' in his definition of pastoral. It is again no coincidence that the word Read used to encompass the mechanics of metaphor serves Empson's pastoral equally well. Metaphor has begun to look like the operating principle of pastoral, so much so that in his essay on Marvell's poem, 'The Garden', subtitled lucidly, 'The Ideal Simplicity approached by Resolving Contradictions', Empson argues that the poct's 'thought is implied by his metaphors' (1995a, p.99). The literary critic James Wood describes metaphor as 'a little explosion of fiction within the larger fiction of the novel 
or story' (2008, p. 153). Warner's delight in metaphor, both locally and constructionally-speaking, is taken in her wartime novel to a new level: 'It was remarkable,' comments a bishop, 'how one metaphor puts you in train for another.' (Warner, 1948 p.187)

As a modus operandi metaphor proved the perfect vehicle for a writer whose express aim, as stated in that lecture of 1959, was to absent herself from the text. We should never, she asserts, be 'conscious of the author's chaperoning presence' (1982a, p.269). Metaphor as well as providing cover for a writcr, particularly one who values their invisibility, has advantages for the reader too. A reader, Warner insists, should experience the 'immediacy' of the text in the same way that a writer experiences 'inspiration': 'immediacy has this in common with inspiration, that where it is present the author becomes absent' (1982a, p. 269). It is through the local consummations of metaphor that 'immediacy' and 'inspiration' collide; that 'sudden perception of an objective relation' re-activated, re-apprehended in the inherently 'present' moment of reading the text.

Warner gives us a vivid characterization of this complex, conflationary relationship. In the mid-1950s she was commissioned to translate Proust's posthumous collection of writings, Contre Sainte-Beuve (1954). In describing the thrill of translation she writes of the 'most unexpected possession' and invokes a story of bucolic metamorphosis: 'Europa swept off on the bull's back could not feel more astonished, proud and powerless' (1982b, p.151). Warner's list of adjectives chronicles the cumulative process of seduction. 'Powerless', imbued with the prevailing association of the words 'astonished' and 'proud', becomes a positive attributc: to be 'powerless' in this context is to allow oneself to be seduced or, as Pope might have put it, 'delighted'. Writing of poctry in her diary Warner notes, "the process [of reading] is more of an identification. The reader must for the space of that sonnet become the writer' (1994, p.42). The reader is not a consumer but one possessed, a relationship predicated on the sort of exquisite paradox 
the metaphysical poets understood so well: 'nor ever chaste, except you ravish me'.

In The Corner That Held Them, the source of pleasure is clearly identified. In middle age the imposter-priest, Sir Ralph, who, as far as protagonists go is the most consistent point of reference, has begun illicitly to take 'his pleasures' with the widow, Magdalen Figg. Through these sexual relations we are told, in a further travesty of his office, his 'spiritual man' is finally awakened:

From every possession of her he emerged with a rediscovered sensibility... He could live in the present, and be as poetical as he pleased.

It is not the first time that Warner has revealed the moment of enlightenment as an ability to live in the present', whose main characteristic can be seen to be an increased propensity for poetical rhapsody. We know that the eponymous Lolly Willowes has truly arrived when at the end of the novel, in answer to the devil asking her what she thinks, she replies, "II don't know...I don't think I do think. I only rhapsodise and make comparisons"' (p.240). The imaginative transformation is seen as one that deliberately subsumes or by-passes intellect.

In Ralph's case the effect is rendered through an orgy of metaphor:

She was smooth as an eel. She walked like a goose. She goggled like a carp. She was dumb as a fish. (Warner, 1948 p.148)

It is also in the privacy of Ralph's new-found 'pleasure' that Warner plunges us directly into the world of Marvell's 'Garden'. She describes Ralph as, 'an unfallen Adam in Paradise' (p.I49): 'If Magdalen Figg, that Eve made of cool clay, had enjoyed this paradise with him, it would not have been paradise' (p.148), lines directly 
reminiscent of 'that happy garden-state' where Adam 'walked without a mate':

Two paradises "twere in one

To live in paradise alone (lines 63-4).

The final epiphany of the novel is riddled with further associations to Marvell's poem. Having escaped the confines of the convent, Dame Lilias comes upon the sea for the first time in her life. 'She looked; and it was as if new eyes had been put into her head.' Beyond the gorse bushes, 'half the world was hung with a blue mantle crisscrossed with an infinity of delicate creases, and the whole outspread mantle stirred as though a scparate life were beneath it.' (p.298).

Meanwhile the mind, from pleasure less,

Withdraws into its happiness:

The mind, that ocean where cach kind

Does straight its own rescmblance find;

Yet it creates, transcending these,

Far other worlds, and other seas;

Annihilating all that's made

To a green thought in a green shade.

(Marvell, 1972 lines 48-55)

Marvell retreats into his corner to find happiness, discovering in his own mind an 'occan'; and then, in typical pastoral proliferation, 'far other worlds, and other seas'. The sea is the very antithesis of the pastoral world, and yet, in the all-embracing spirit of the tradition, it is just as available as an image as any other. In the mind's/sca's capacity as a receptacle for 'all that's made', the possibility is raised for that 'all' to become 'nothing': the annihilating, ultimate consummation of a 'green thought in a green shade'. This is the moment when language fails, where identical words find and cancel each other out. Dame Lilias's reaction to her 'sudden perception' of the sea is one of sheer pleasure. She laughs 
out loud, waking up her fellow nun who asks her why on earth she is laughing. Dame Lilias replies, 'For joy' (p.298).

Roland Barthes, in the rhapsodic fragments that make up his thoughts on 'the pleasure of the text', describes how it is possible for 'narrativity...[to be] dismantled yet the story... still readable'. If, he says, a reader,

appreciates controlled discontinuities,
faked conformities, and indirect
destructions. In addition to the success
which can here be attributed to an author,
there is also, here, a pleasure of
performance: the feat is to sustain the
mimesis of language...the source of
immense pleasures...

Mimesis, as Barthes deploys the word, contains an awareness of those two worlds outlined by Raymond Williams: a distinction of the world that is being performed in language and the real world. It is a distinction that does not privilege one over the other, or the writer over the reader.

There is a point in Warner's novel when this effect is given emphatic amplification. In the penultimate chapter, "A Green Staff', Ralph is presented an old man. Some twenty years before he had been entrusted with the manuscript of a blind poet's unfinished work, "The Lay of Mamillion', a poem written in the demotic language and rhythms of English, which Ralph, schooled in Latin, finds alien to his ear. It is only through repeated reading of the work that he finally makes a breakthrough, arriving at:

that passage about the wild man, who capered up to Mamillion and smote him with a flowering branch, filling his nose and eyes with pollen-dust; and before Mamillion could clear his eycs and leave off sneezing the wild man had capered away again... 
The image of assault, a moment later, becomes the vehicle that will describe Ralph's 'astounded' apprehension of the poem's brilliance: 'at last came a reading which became a first reading, and he had been as much astounded as if he too had been smitten over the nose with a flowering branch.'(p.274)

The 'flowering branch', an image born from the text itself, can be seen to achieve its metaphoric effect simultaneously in three distinct worlds: the world of the 'Mamillion' text; the world in which Ralph is situated as he apprehends this text; the world of the reader of the novel at hand. Metaphor creates a hall of mirrors that continuously compares and differentiates between worlds: the actual world of physical reality and the exquisitely present, intimately discreet world we enter when, in the process of reading, we enter an 'other' world; in evoking one world, it generally adumbrates another.

Empson's great achievement was to remove the layers of varnish from the pastoral; by dissceting and oiling its workings, to show how active and useful a tool it could be. In 2009 Peter Conrad was able to ask whether: 'English culturc in all its facets, from Shakespeare's Falstaff babbling of green ficlds to Martin Amis grimly taking stock of London Fields... doesn't simply consist of what William Empson called "some versions of pastoral". (Conrad, 2009) Warner meanwhile demonstrated that, through attention to a method that made a virtuc of its artifice and limitations, the pastoral was capable of supplying a blueprint that might even account for the way in which writers write and readers read: "For each of us lives in his microcosm, the solidity of this world is a mere game of mirrors, there can be no absolute existence for what is apprehended differently by all' (Warner 1948, p. 215). It is a tribute to her mastery of that peculiarly rhapsodic version that in a review of the 1972 reissue of The Corner That Held Them, Nina Bawden concludes that she, 'seems to write as effortlessly as a bird sings'. True to Pope, Warner peddled no 'message' other than to delight, or as Heaney phrases it, 
to put "self-delighting buds on the old bough of a tradition" (Heaney, 1980 p.173). Her trick was to make the old tradition new, to make it sing spontancously as if, for that moment, nothing else mattered.

\section{WORKS CITED}

BACHELARD, G. (1969) The Poetics of Space, transl. Maria Jolas. Boston: Beacon Press.

BARTHES, R. (1975) The Pleasure of the Text. Translated by Richard Miller. New York: Hill and Wang. BAWDEN, N. (1972) Review of The Corner That Held Them (Chatto and Windus, reissue) in Telegraph ?n.d. The Sylvia Townsend Warner Archive, Dorset County Museum, Dorchester.

CONRAD, P. (2009) 'Even his trees still seem to talk to us'. Observer 12 April.

EMPSON, W. (1995a) Seven Types of Ambiguity. 1930. London: Penguin.

(1995b) Some Versions of Pastoral. 1935. With a prefatory note by Lisa A. Rodensky. London: Penguin.

GARNETT, R. (Ed.) (1994) Sylvia and David: The Townsend Warner/Garnett Letters. London: SinclairStevenson,

HARTLEY, L.P. (1926) 'New Fiction' Saturday Review 6 February 1926: 165.

HEANEY, S. (1980) Preoccupations, Selected Prose 1968-78. London: Faber.

London: Faber.

(1995) The Redress of Poetry: Oxford Lectures.

MARVELL, A. (1972). The Complete Poems. London: Penguin.

ORWELL, G. (1939) Coming up for Air. London: Gollancz, 1939.

POPE, A. (1936) 'A Discourse on Pastoral Poetry' from The Prose Works of Alexander Pope, Vol.I. The Earlier Works 1711 - 1720. Ed. Norman Ault. Oxford: Blackwells. 
SCHMIDT, M. and WARNER, V. (2002) 'Sylvia Townsend Warner in Conversation'. First published in $P N$ Review 23, 1981. Reprinted in the Journal of the Sylvia Townsend Warner Society, pp.43 - 52.

WARNER, S. T. (1948) The Corner That Held Them. London: Chatto and Windus.

_ 'Extracts from The Corner. That Held Them in 4 sections'. ts. N (Upper left) 9. The Sylvia Townsend Warner Archive, Dorset County Museum, Dorchester. (1978) Lolly Willowes. London: The Women's Press.

(1982a) Collected Poems Ed. Claire Harman. Manchester: Carcanet (1982b) Letters. Ed. William Maxwell. London: Chatto and Windus.

(1994) The Diaries of Sylvia Townsend Warner. Ed. Claire Harman. London: Chatto and Windus. (2007) 'The Way I Have Come', The Jounal of the Sylvia Townsend Warner Society pp.1-9.

WILliAMS, R. (1973) The Country and the City. London: Chatto and Windus.

WOOD, J. (2008) How Fiction Works. London: Jonathan Cape. 